\title{
pT1N0M0 非小細胞肺癌切除例の遠隔成績の検討
}

\author{
小林孝一郎，佐藤日出夫，坪田誠，岩喬
}

\begin{abstract}
要旨
石川県立中央病院に预いて1982年から1993年の間に原発性肺癌として手術した283例のらち $\mathrm{T} 1 \mathrm{~N} 0 \mathrm{M} 0$ 非小細胞肺癌54例（19\%）の手術成績について検討した．T1N0M0 症例全体の 5 年生存率は 91\%で，腺癌は $84 \%$, 扁平上皮癌では癌死例はなかった. 腺癌では絶対的治癒切除を行った 33 例中 6 例（18\%）に再発・転移を認めた．腫瘍径が21 30 mm の群は，20 mm 以下の群と比較して有意に予 後不良であった.ささら，分化度が高分化ょり中分化，中分化ょり低分化の方が有意に予後不良であっ た. T1N0M0 扁平上皮癌では絶対的治癒切除により治瘾が期待できるが，T $1 \mathrm{~N} 0 \mathrm{M} 0$ 腺癌では絶対的治 癒切除を行っても再発・転移例は少なくない．とくに腫瘍径が21～30 mm や低分化の症例の予後は悪 く, 予後向上のためには潜在性遠隔転移に対する術後補助療法が必要であり, 現時点では化学療法が最 適と思われ，今後積極的に補助化学療法を施行したい。
\end{abstract}

索引用語：T1N0M0 非小細胞肺癌, 分化度, 腫瘍径, 補助化学療法

T1N0M0 non-small cell lung cancer, differentiation, tumor diameter, postoperative chemotherapy

\section{はじめに}

近年肺癌羅患率は増え続けて抢り, 肺癌死亡 者数も多くなってきている. 最も治癒の可能性 が高いと考兄られる病期 I 期症例でも約 $1 / 4$ の 症例が再発死亡して拉り，その予後は不良であ る. そのなかで比較的予後良好な T1N0M0 肺 癌の手術成績を統計学的に検討し，その予後に 及ぼす因子について考察した.

\section{対象と方法}

石川県立中央病院に预いて1982年から1993年 までの11年間に肺切除術を施行した原発性肺癌 は283例あり，T1N0M0 症例は57例（20\%）で あった。このうち症例数の少ない大細胞癌 1 例 とカルチノイド 2 例を除く54例（19\%）につい

石川県立中央病院 胸部外科

原稿受付 1994年 5 月 26 日

原稿採択 1994年 7 月 29日
て術後の追跡調查を行い, その結果を統計学的 に検討した．生存率は Kaplan-Meier 法にて計 算し，有意差検定は一般化 Wilcoxon test い, $\mathrm{p}<0.05$ 有意とした.

\section{結果}

年齢は 40 ～81歳で平均65歳であった．性別は 男性37例，女性17例であった．組織別では，扁 平上皮癌15例 (26\%), 腺癌39例 (67\%) であっ た. 癌腫の発生部位は, 右上葉が19例, 右中葉 が 1 例，右下葉が 7 例，左上葉が 17 例，左下葉 が10例であった。 根治度は, 肺葉切除とリンパ 節郭清を行った絶対的治癒切除 48 例, 部分切除 にとどめた相対的非治癒切除 6 例であった．部 分切除例はすべて高齢者の末梢型腺癌であった

(Table 1).

$\mathrm{T} 1 \mathrm{~N} 0 \mathrm{M} 0$ 症例全体の 5 年生存率 (以下, 5 生 率)は $91 \%$ で，腺癌は $84 \%$, 扁平上皮癌は $100 \%$ であった. 9 年生存率では, 腺癌は $72 \%$, 扁平 上皮癌は $100 \%$ で癌死例はなかった（Fig. 1). 
Table 1 Charactaristics of 54 patients with nonsmall cell lung cancer.

\begin{tabular}{|c|c|c|c|}
\hline & & $S q(n=15)$ & $\operatorname{Ad}(n=39)$ \\
\hline \multirow[t]{2}{*}{ Age } & & $48-71$ & $40-81$ \\
\hline & Mean & 67.7 & 64.6 \\
\hline Sex & Male : Female & $14: 1$ & $23: 16$ \\
\hline \multirow[t]{5}{*}{ Location } & Rt. upper lobe & 4 & 15 \\
\hline & middle lobe & 0 & 1 \\
\hline & lower lobe & 1 & 6 \\
\hline & Lt. upper lobe & 8 & 9 \\
\hline & lower lobe & 2 & 8 \\
\hline \multirow[t]{2}{*}{ Curability } & Curative & 15 & 33 \\
\hline & Non-curative & 0 & 6 \\
\hline \multicolumn{4}{|c|}{ Differentiation } \\
\hline & Well & 6 & 21 \\
\hline & moderately & 7 & 10 \\
\hline & poorly & 2 & 8 \\
\hline \multicolumn{4}{|c|}{ Tumor diameter (mm) } \\
\hline . & $0-20$ & 12 & 19 \\
\hline & $21-30$ & 3 & 20 \\
\hline
\end{tabular}

$\mathrm{Sq}$ : Squamous cell carcinoma;

$\mathrm{Ad}$ : Adenocarcinoma

T1N0M0 腺癌では絶対的治癒切除を行った 33 例中 6 例 $(18 \%)$ に再発・転移を認めた。こ のうち 5 年以内の癌死例は 4 例であった，死因 は, 脳転移, 肺転移, 癌性胸膜炎, 骨転移と様々

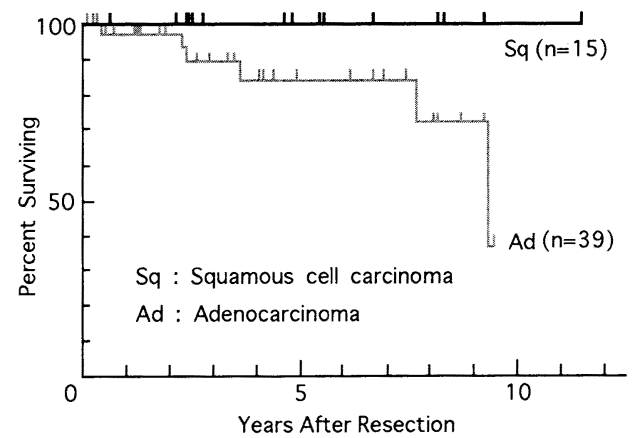

Fig. 1 Survival rates of patients with resected pT1N0M0 lung cancer, according to histological type.

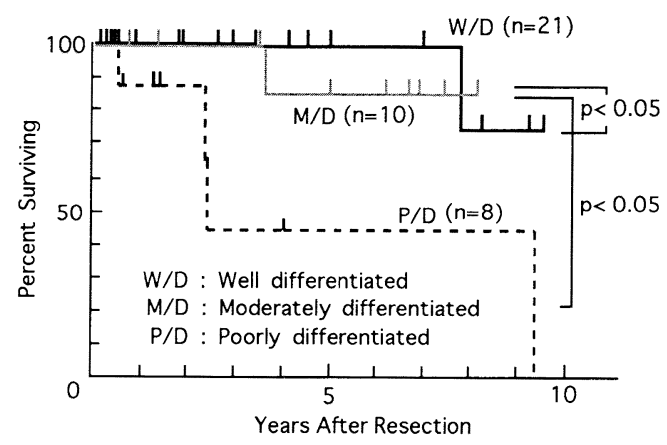

Fig. 2 Survival rates of patients with resected pT1N0M0 adenocarcinoma, according to differentiation.

Table 2 Four patients who died within 5 years after resection of pT1N0M0 adenocarcinoma.

\begin{tabular}{ccclcccl}
\hline Case & Age & Sex & Curability & Diff. Size $(\mathrm{mm})$ & Survival & Cause of death \\
\hline 1 & 55 & M & Curative & P/D & 30 & $5 \mathrm{M}$ & Brain meta. \\
2 & 67 & F & Curative & P/D & 30 & $27 \mathrm{M}$ & Brain meta. \\
3 & 69 & M & Curative & P/D & 25 & $28 M$ & Bil. Lung meta. \\
4 & 76 & F & Curative & M/D & 30 & $43 M$ & Pleuritis \\
& & & & & & & Bone meta.
\end{tabular}

Diff. : Differentiation; P/D : Poorly differentiated;

$M / D$ : Moderately differentiated; meta. : Metastasis

Table 3 Five patients who received chemotherapy after resection of pT1N0M0 adenocarcinoma.

\begin{tabular}{cccccccl}
\hline Case & Age Sex & Curability & Diff. & Size $(\mathrm{mm})$ & Outcome & Regimen \\
\hline 1 & 50 & $\mathrm{~F}$ & Curative & P/D & $29 \mathrm{~mm}$ & $14 M$,Alive & CDDP+VDS \\
2 & 64 & $\mathrm{~F}$ & Curative & W/D & $20 \mathrm{~mm}$ & $98 M$,Alive & CDDP+VDS \\
3 & 40 & $\mathrm{M}$ & Curative & W/D & $20 \mathrm{~mm}$ & $110 M$,Alive & CDDP+ADM+VCR \\
4 & 65 & $\mathrm{~F}$ & Curative & P/D & $23 \mathrm{~mm}$ & $112 \mathrm{M}$,Dead & CPA+ADM+5-FU \\
5 & 53 & $\mathrm{~F}$ & Curative & W/D & $30 \mathrm{~mm}$ & $114 \mathrm{M}$,Alive & ADM+5-FU \\
\hline \multicolumn{7}{l}{ W/D : Well differentiated }
\end{tabular}




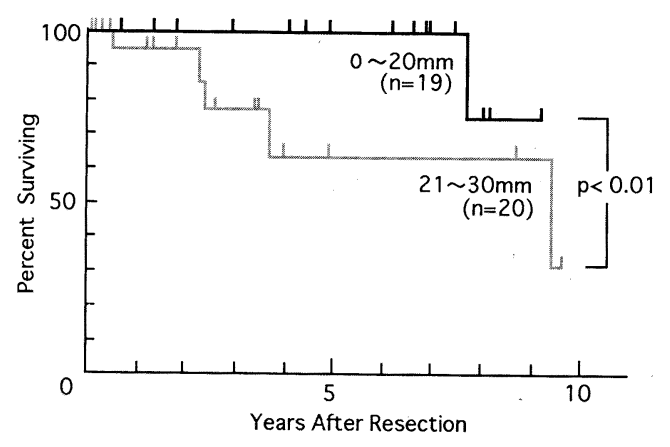

Fig. 3 Survival rates of patients with resected pT1N0M0 adenocarcinoma, according to tumor diameter.

であるが，いずれの症例も低分化もしくは中分 化で, 腫瘍径が $21 \mathrm{~mm}$ 以上であることが共通し ていた（Table. 2).

そこで，分化度別に予後を検討すると， 5 生 率はそれぞれ高分化(21例)が100\%，中分化(10 例） より中分化，中分化より低分化の方が有意に予 後不良であった (Fig. 2).

腫瘍径別に予後を検討すると，5生率はそれ ぞれ腫瘍径が $20 \mathrm{~mm}$ 以下（19例）が100\%, 21 30 mm (20例) が64\%で, 21 30 mm の症 例は $20 \mathrm{~mm}$ 以下の症例と比較して有意に予後 不良であった (Fig. 3).

予後不良な腺癌症例のらち術後補助化学療法 を行った 5 例では, 低分化腺癌が 2 例, 腫瘍径 が $21 \mathrm{~mm}$ 以上が 3 例含まれているが，4例が 8 年以上の生存を得て括り, 万ち 3 例が生存中で ある (Table 3).

\section{考察}

T1N0M0 非小細胞肺癌手術症例の 5 生率は, Williams ら ${ }^{11} 80 \%$, Read ら ${ }^{2)} 78 \%$ のよに $80 \%$ 前後の報告が多いが，当施設では $91 \%$ と他施設 に比べて予後良好であった。. これは, 扁平上皮 癌の 5 生率が $100 \%$ と他施設の $\operatorname{Read} ら^{2)} 81 \%$, 木村ら ${ }^{3} 84 \%$ に比べて極めて良好であったため であるが，扁平上皮癌に执いては手術により治 癒が期待できると考学られた。 また，肺野型の 症例では部分切除と肺葉切除に予後の差はなく
縮小手術も提唱されている ${ }^{2,4,5)}$.

これに対して, 腺癌の 5 生率は当施設の $84 \%$ をはじめ西村ら ${ }^{6} 83.5 \%$ ，木村ら ${ }^{3)} 74 \%$ と多くの 施設で有意差をもって扁平上皮癌より予後不良 となっている ${ }^{2,3,6,7)}$. そこで, 腺癌の予後に関与 すると思われる因子として, 分化度や腫瘍径に ついて検討した. 分化度別では, 高分化より中 分化, 中分化上り低分化の予後が有意に不良で あり，同様の報告 ${ }^{3)}$ と共に有意差がなかったと の報告 ${ }^{8}$ や東山 ( $^{9}$ の病期 I 期再発・癌死例の検 討で低分化を 1 例も認めなかったとの報告も見 られ，一定の傾向が認められない. 腫瘍径別で は20 mm 以下と 21 30 mm とに分けて予後を 検討したところ有意差を認めた. Read ら ${ }^{10)}$ は TNM 分類が正しく予後を反映するためには T1 20 mm 以下にすべきであると述べている。 しかしながら，東山ら ${ }^{9)}$ にれば， $20 \mathrm{~mm}$ 以下 の $\mathrm{N} 0$ 症例でも再発・癌死例は $31 \%$ に及び, 予後の悪い小型肺腺癌の存在を警告している. また, 相対的非治癒切除 6 例のらち肺・遠隔転 移が 5 例と高率にみられることから，標準術式 としての縱隔リンパ節郭清の意義は大きいと述 ベている ${ }^{9)}$.

術後化学療法の有用性については否定的な意 見が多い ${ }^{11)}$ が, T1N0M0 腺癌の肺・遠隔転移再 発例では, 腫瘍内線維化巣と血管侵襲が著しい ことから比較的長い担癌期間中に癌細胞の血管 侵襲が発生して遠隔転移をもたらしていると考 えられる こと, 絶対的治癒切除をなしえても な拉 $20 \%$ 前後に再発・遠隔転移を認める ${ }^{8)}$ こ， 局所再発より遠隔転移が 2 倍以上多い(3) と等 から，予後向上のためには潜在性遠隔転移に対 する術後補助療法が必要と考光る。現時点では 化学療法が最適と思われる. 現在の CDDPを中 心とした化学療法には限界がありさらに有効な 薬剤の出現が期待されるところであるが, T1N0M0 腺癌のらち低分化型あるいは腫瘍径 $21 \mathrm{~mm}$ 以上の症例の補助化学療法施行例を重 ねてさらなる検討をしたい。

\section{結語}

T1N0M0 非小細胞肺癌手術症例54例の予後 
について検討した.

1） 5 生率はそれぞれ，扁平上皮癌が $100 \% ，$ 腺 癌が84\%であった。

2 ) 腺癌症例では, 腫瘍径が $21 \mathrm{~mm}$ 以上や分化 度が低い症例の予後が特に不良であった。

3） T1N0M0 扁平上皮癌では絶対的治癒切除 により治癒が期待できるが, T1N0M0 腺癌では 絶対的治癒切除を行っても再発・転移例は少な くない.とくに低分化型や腫瘍径が $21 \mathrm{~mm}$ 以上 の症例の予後は悪く, 積極的な補助化学療法が 必要と考光られた。

な抒，本論文の要旨の一部は，第11回日本呼 吸器外科学会総会 (1994年 5 月, 京都) にて発 表した.

\section{文献}

1) Williams DE, Pairolero PC, Davis CS, et al: Survival of patients surgically treated for Stage I Iung cancer. J Thorac Cardiovasc Surg 82:70-76, 1981.

2) Read RC, Yoder G, Scheffer RC: Survival after conservative resection for T1N0M0 non-small cell lung cancer. Ann Thorac Surg 49: 391-400, 1990.
3）木村 誠, 谷 一浩, 竹内義広, 他: 術後遠隔成 績からみた肺腺癌外科治療の検討. 胸部外科 $43: 2-9,1990$.

4) Hoffmann TH, Ransdell HT : Comparison of lobectomy and wedge resection for carcinoma of the lung. $\mathrm{J}$ Thorac Cardiovasc Surg 79:211-217, 1980.

5）高森信三，原 信之，一瀬幸人，他：Stage I 扁 平上皮癌の検討. 日呼外会誌 $6: 125-128$, 1992.

6）西村秀紀, 森本雅巳, 羽生田正行, 他：I - II 期肺癌治療切除例の予後の検討. 胸部外科 45:582-585, 1992.

7) Thomas $P$, Rubinstein $L$ : Cancer recurrence after resection: T1N0 non-small cell lung cancer. Ann Thorac Surg 49 : 424-247, 1990.

8）西村秀紀, 青木考學, 矢満田健, 他：pT1N0M0 非小細胞肺癌の手術成績. 日呼外会誌 6 ： 432-439. 1992.

9）東山聖彦，土井 修，児玉 憲，他：予後の悪 い小型肺腺癌の生物学的特性一臨床病理学的 検討による小型肺腺癌の特徵一. 胸部外科 44:33-37, 1991.

10) Read RC, Schaefer R, Walls R: Diameter, cell type, and survival in stage I primary non -small-cell lung canser. Arch Surg $123: 446^{-}$ 449, 1988.

11）山口 豊，木村秀樹，馬場雅行，他：肺癌手術 の治療成績とその現況. 臨外 $45: 51-55$, 1990.

\title{
Survival of patients after surgery for pT1N0M0 non-small cell lung cancer
}

\author{
Koichiro Kobayashi, Hideo Sato, Makoto Tsubota, Takashi Iwa
}

Department of Thoracic Surgery, Ishikawa Prefectural Central Hospital, Kanazawa, Japan

Fifty-seven patient with pT1N0M0 non-small cell lung cancer underwent pulmonary resection at Ishikawa Prefectural Central Hospital between 1982 and 1993. The results of treatment were assessed retrospectively. The overall 5-year survival rate was $91 \%$. In 39 patients with adenocarcinoma it was $84 \%$, and in 15 patients with squamous cell carcinoma it was $100 \%$. Cancer recurred in $18 \%$ of adenocarcinoma patients after absolute curative resection. There were significant differences in survival rates between patients with well differentiated and moderately differentiated adenocarcinoma, and between those with moderately differentiated and poorly differentiated adenocarcinoma. The diameter of the adenocarcinoma was also related significantly to lenght of survival (less than $20 \mathrm{~mm}$ versus $21-30 \mathrm{~mm}$ ). We conclude that postoperative chemotherapy is important for $21-30 \mathrm{~mm}$ or poorly differentiated adenocarcinoma. 